\title{
Identificação de Mycobacterium avium subsp. Paratuberculosis (map) através da bacterioscopia em búfalos abatidos na Baixada Maranhense
}

Thais Bastos Rocha, Emerson Antônio Araújo de Oliveira, Carolina Rodrigues Torres, Diego Moraes Soares, Hamilton Pereira

Santos, Helder de Moraes Pereira'

Universidade Estadual do Maranhão (UEMA), São Luís, MA, Brasil

*Autor correspondente

e-mail: helderpereirap@yahoo.com.br

\section{Resumo}

A paratuberculose é considerada uma enterite crônica granulomatosa, incurável, causada pelo Mycobacterium avium subsp. paratuberculosis (MAP), que afeta principalmente os ruminantes, podendo atingir também outras espécies de animais. É responsável por perdas econômicas, que ocorrem pela redução na produtividade e maior susceptibilidade a outras doenças, causando um considerável impacto na economia. Desta forma, o objetivo do presente trabalho foi diagnosticar o Mycobacterium avium subsp. paratuberculosis (MAP) nos rebanhos bubalinos abatidos na região da Baixada Maranhense. Foram coletadas amostras de intestino delgado, intestino grosso, linfonodos mesentéricos e fezes de 115 búfalos abatidos em matadouros da Baixada Maranhense. Para o diagnóstico dessa enfermidade, foram realizados exames histopatológicos utilizando as colorações de Hematoxilina e Eosina (H\&E), Ziehl-Neelsen (ZN) e isolamento bacteriano. Foi possível evidenciar infiltrado inflamatório granulomatoso composto por macrófagos epiteliódes repleto de células gigantes tipo Langhans na mucosa, infiltrado mononuclear na submucosa, com atrofia e fusão das vilosidades no intestino delgado, e infiltrado difuso acentuado de macrófagos epitelióides e células gigantes tipo Langhans nos linfonodos mesentéricos em 27\% (31/115) dos búfalos. Essa infiltração de macrófagos na mucosa e submucosa com atrofia e fusão de vilosidades no intestino delgado de forma acentuada e multifocal, acompanhados da visualização de bacilo álcool - ácido - resistente (BAAR) à coloração de Ziehl-Neelsen, é semelhante aos encontrados em búfalos com paratuberculose nos municípios de São Mateus e São Luís, no Maranhão. Com a coloração de Ziehl-Neelsen, foram visualizados bacilos álcool-ácido-resistentes (BAAR) em 23\% (26/115) das amostras dos tecidos analisados. Entretanto, cinco animais que apresentaram lesões de paratuberculose subclinica quando corados em Hematoxilina e Eosina (HE) apresentaram-se negativos quando submetidos à técnica de coloração de ZN. Nas amostras de fezes submetidas ao cultivo bacteriano foi identificado o Mycobacterium avium subsp. paratuberculosis em 19\% (5/26). Foi possível observar colônias 
redondas, brancas, lisas e levemente rugosas, coloração álcool-ácido e crescimento lento com oito semanas de incubação e dependência de micobactina. 0 tempo de crescimento das colônias compatíveis com o MAP em amostras de fezes variam de oito a doze semanas; os achados foram semelhantes aos relatados na Índia, que detectaram seis búfalos positivos no cultivo bacteriológico, depois de 12 semanas de incubação. Os resultados desse estudo demonstram a ocorrência subclínica de paratuberculose em rebanhos bubalinos abatidos em matadouros da Baixada Maranhense. 